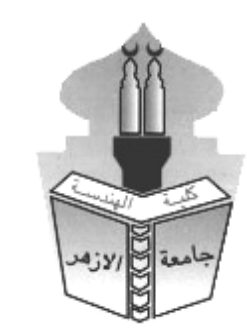

\title{
EFFECT OF JOINT DETAILS ON THE BEHAVIOR OF RC BEAM COLUMN CONNECTIONS SUBJECTED TO REVERSED CYCLIC LOADING
}

\author{
Ahmed Abdel Hafiz Mahmoud \\ Civil Engineering Department, Faculty of Engineering, Al-Azhar University.
}

\begin{abstract}
This study summarizes the test results of six half scale reinforced concrete beam-column connections subjected to reverse cyclic loading up to failure. The main parameter among the tests specimens was the joint shear reinforcement details. Five specimens included different joint shear reinforcement details and one without any shear reinforcement. The reinforcement details included U-shaped stirrups, joint crossbars, and closed stirrups. Test results indicated superior behavior for specimens with closed stirrups over other joint reinforcement details.

In addition, the accuracy of some mechanical models against tests results was assessed. Two models provided accurate joint shear strength predictions while other models either over or underestimated the capacity of the connections. Vollum model accurately predicted shear strength of the joint without shear reinforcement. Tran model accurately predicted the ultimate joint shear strength of the joints with closed stirrups. All models overestimated the shear strength of joints with U-shaped stirrups.
\end{abstract}

\section{Keywords: Beam-Column Connections, Shear Strength, Cyclic Loading, Joint Details, Experimental Results, Mechanical Models.}

\subsection{INTRODUCTION}

The reinforced concrete frame system is widely used in construction operations among the world. When the structure is subjected to gravity or lateral loads, the joints connecting beam and column (especially exterior joints) are subjected to complex straining actions that may lead to joint shear failure. Previous researchers [2,5-7] indicated several parameters affecting the shear strength of beam-column joints. The amount of joint shear reinforcement is one of the most important parameters that affect the joint shear strength of exterior beam-column connections. However, the efficiency of different shear reinforcement shapes and details are not yet well studied.

In addition, ultimate joint shear strength can be evaluated either using code like formulations or empirical models [3]. Code like formulations represents joint shear strength in terms of concrete nominal shear strength. The advantage of this approach is the simplicity and ease of use. On the other hand, the predictions of these formulas are usually conservative and underestimated. Empirical and semi-empirical models usually employ mechanical approaches to represent the flow of forces in the joint region. Despite the complicity of such models, it is relatively accurate since it is always verified against experimental results with good agreement. However, in the past two decades, several models for shear strength of beam-column joints were proposed [1, 2, 5-7]. 
In this paper, the efficiency of different joint shear reinforcement details is experimentally investigated. In addition, the accuracy of some empirical models and code formulations is examined against experimental results. These models are briefly discussed in the following paragraphs.

\subsection{MODELS FOR BEAM COLUMN JOINT SHEAR STRENGTH}

According to ACI 318-R02 provisions, the nominal shear strength of the joint is [1]

$$
V_{\mathrm{n}}=0.083 \gamma \sqrt{f_{c}^{2}} b_{j} \boldsymbol{h}_{c} \quad(\mathrm{Mpa})
$$

Where $b_{j}$ is the effective joint width, $h_{c}$ is the column depth in the analysis direction, and $\gamma$ is a factor to account for joint confinement by adjacent beams. ACI formula represents the joint shear strength as a function of the square root of the concrete compressive strength and the confinement condition by adjacent beams. However, many researchers [2, 5-7] indicated other parameters to affect the joint shear strength of exterior joints such as joint aspect ratio, amount of beam reinforcement, amount of joint transverse reinforcement, and column axial load.

Vollum R.L. and J.B. Newman (1999) [6] developed a strut and tie model for the analysis and design of external beam column connections. Vollum model accounts for the effects of both joint aspect ratio and shear reinforcement. The portion of shear stress carried by reinforcement was calculated using stiffness analysis. According to Vollum [6], the joint shear strength is the greater of $\mathrm{V}_{\mathrm{c}}$ and $\mathrm{V}_{\mathrm{j}}$ given by the following equations:

$$
\begin{array}{ll}
V_{j}=\left(V_{c}-\alpha b_{c} \boldsymbol{h}_{c} \sqrt{f_{c}^{2}}\right)+A_{s j} f_{y} & 2 \\
V_{c}=0.624 \beta\left[1+0.555\left(2-\boldsymbol{h}_{b} / \boldsymbol{h}_{c}\right)\right] b_{e} \boldsymbol{h}_{c} \sqrt{f_{c}^{*}} & 3
\end{array}
$$

Where $V_{c}$ is the joint shear strength without stirrups, $A_{s j}$ is the effective stirrups area in joint region, $\mathrm{f}_{\mathrm{y}}$ is the yield strength of the stirrups, $\alpha$ is an efficiency factor which depends on column load, the concrete strength, amount and yield strength of stirrups, and the joint aspect ratio. And $\beta$ is a factor to account for bar shape.

In addition, based on experimental results, Bakir P.G. (2002) [5] developed a design equation for shear strength prediction of monotonically loaded exterior beam column joints. Bakir equation accounts for the beam reinforcement ratio, joint aspect ratio, and amount of stirrups. In Bakir equation, a factor $\alpha$ was implemented to account for stirrup contribution to joint shear capacity. The factor $\alpha$ is in an inverse proportion with the stirrup volume as the ability of stirrups to yield will decrease with increasing the amount of stirrups as follows:

$$
V_{j}=\frac{0.71 \beta \gamma\left(100 \times \frac{A_{s b}}{b_{b} d_{b}}\right)^{0.4289}\left(\frac{b_{c}+b_{b}}{2}\right) \boldsymbol{h}_{c} \sqrt{f_{c}^{*}}}{\left(\frac{\boldsymbol{h}_{b}}{\boldsymbol{h}_{c}}\right)^{0.61}}+\alpha A_{s j e} f_{y}
$$

Where $\alpha=0.664$ for joints with stirrup ratio less than 0.003

$\alpha=0.6$ for joints with stirrup ratio between 0.003 and 0.0055

$\alpha=0.37$ for joints with stirrup ratio more than 0.0055

Moreover, Hegger et.al (2003) [2] developed a formula for the shear strength of exterior beam column joints. Amount and shape of stirrups are taken into account in Hegger equation as follows:

$v_{n}=v_{c}+v_{s} \leq v_{\max }$

Where $v_{c}$ and $v_{s}$ are shear resistances of both concrete and stirrups respectively, and $v_{\max }$ is the maximum shear strength of the connection, to be calculated as follows: 
EFFECT OF JOINT DETAILS ON THE BEHAVIOR OF RC BEAM COLUMN CONNECTIONS SUBJECTED TO REVERSED CYCLIC LOADING

$$
v_{c}=\alpha_{1}\left(2.4-0.6 \frac{\boldsymbol{h}_{b}}{\boldsymbol{h}_{c}}\right)\left(1.0+\frac{\rho_{\text {col }}-0.5}{7.5}\right)\left(f_{c}^{*}\right)^{1 / g}
$$

Where $\alpha_{1}$ is a factor to account for the anchorage efficiency of beam reinforcement, $\alpha_{1}$ equals 0.85 for 180-degree bent bars and 0.95 for 90-degree bent or headed bars. Hegger equation is valid for joints with aspect ratio between 0.75 and 2.0, and column reinforcement ratio between 0.5 and 2.0 .

$v_{s}=\frac{\alpha_{\mathbf{2}} A_{s j, e f f} f_{y}}{b_{i} h_{c}}$

Where $\alpha_{2}$ is a factor to reflect the efficiency of shear reinforcement depending on the stirrups shape, $A_{\text {sj,eff }}$ is the effective shear reinforcement area inside the joint, and $f_{y}$ is the stirrups yield strength. According to Hegger et al. [2], joint maximum shear strength is limited by the following equation.

$$
v_{\max }=0.25 \gamma_{1} \gamma_{2} \gamma_{3} f_{c}^{*} \leq 2 v_{c}
$$

Where $\gamma_{1}$ is a factor accounting for anchorage effectiveness of the beam reinforcement, $\gamma_{2}$ is a factor to account for column axial stress, and $\gamma_{3}$ is a factor to account for joint aspect ratio. Furthermore, Tran et al. (2014) [7] developed an empirical model to predict joint shear strength of both interior and exterior beam column joints. Tran model accounts for joint horizontal and vertical shear reinforcement, joint aspect ratio, amount of beam flexural reinforcement and bar size. According to Tran, joint shear strength is:

$$
V_{j h}=\left(\gamma_{1}+\frac{N}{b_{c} h_{c} f_{c}^{*}}+1.2 \gamma_{b}\right) A_{j h}\left(f_{c}^{*}\right)^{0.5}+\gamma_{2}\left(A_{s j h} f_{j h y}+A_{s j v} f_{j v y}\right)
$$

Where $\mathrm{A}_{\mathrm{sjh}}$ and $\mathrm{A}_{\mathrm{sjv}}$ are horizontal and vertical joint shear reinforcement, respectively.

Where $A_{\text {sjh }}$ and $A_{s j v}$ is horizontal and vertical joint shear reinforcement, respectively, $f_{j h y}$ and $f_{j v y}$ is yield strength of horizontal and vertical joint shear reinforcement, respectively. $A_{j h}$ is the effective joint area, $\gamma_{1}$ and $\gamma_{2}$ are factors depending on the joint type (interior or exterior joint). $\mathrm{N}$ is the column axial load, $b_{c}$ and $h_{c}$ are the dimensions of column cross section.

In Tran model [7], to account for beam reinforcement, a new parameter $\left(\chi_{b}\right)$ was proposed. $\left(\chi_{b}\right)$ is the beam bar index and can be calculated as follows:

$$
\chi_{b}=\left(\frac{n_{b} d_{s b}}{b_{b}} \frac{\boldsymbol{h}_{c}}{\boldsymbol{h}_{b}}\right) \leq \mathbf{0 . 4}
$$

Where $n_{b}$ is the maximum number of beam bottom and top bars, $d_{s b}$ is the average diameter of beam tensile reinforcement, $b_{b}$ is the beam width, $h_{b}$ is the beam height.

3. Experimental program.

In the reinforced concrete laboratory of the Housing and Building National Research Center (HRBC), an experimental campaign was carried out in order to investigate the cyclic behavior of corner RC beam-column connections with different reinforcement detailing.

3.1 Test specimens

Six half scale corner beam-column joints were tested under unidirectional reversed cyclic loading up to failure. The tested specimens were designated as J1G3, J2G3, J3G3, J4G3, J2G4, and J3G4. 
Figure (1) shows the reinforcing details of the specimens. For all specimens, the beams were reinforced symmetrically with top and bottom bars of 7T12. Top and bottom bars were bent out of the joint for all specimens except specimens J2G4, and J3G4. The latter specimens were provided with top and bottom beam bars bent into the joint. In addition, all specimens' columns included symmetric reinforcement of 5T12 each side, while the joint shear reinforcement was variable as follows:

- $\quad$ For specimen J1G3 (control specimen), no joint shear reinforcement was provided.

- $\quad$ For Specimen J2G3, the joint was provided with U-shaped stirrups of 2T12.

- $\quad$ For Specimen J3G3, the joint was provided with crossbars of 2T12 in the column, the cross bars were lapping each side of the column longitudinal bars together.

- $\quad$ For specimen J4G3, the joint was provided with crossbars of 2T12, the cross bars were lapping beam top and bottom bars with column bars.

- $\quad$ For specimen J2G4, the joint was provided with closed stirrups of 3R8.

- $\quad$ For specimen J3G4, the joint was provided with closed stirrups of 5R8.

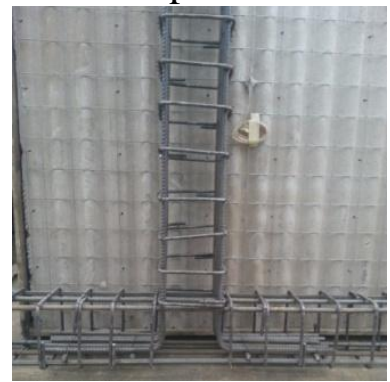

(a) J1G3

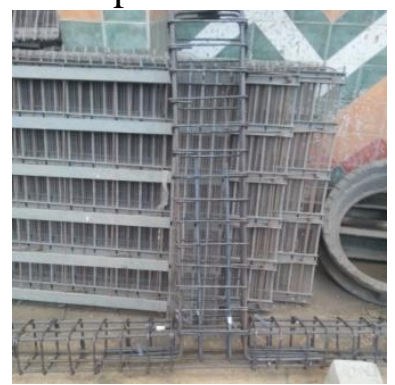

(b) J2G3

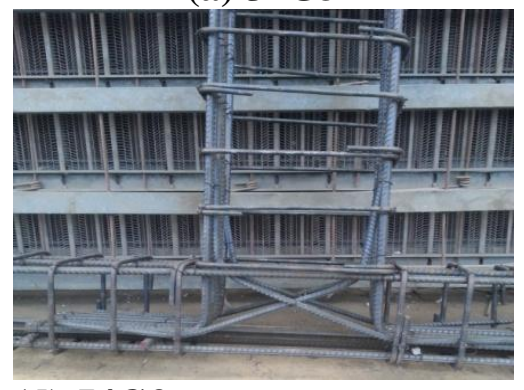

(d) J4G3

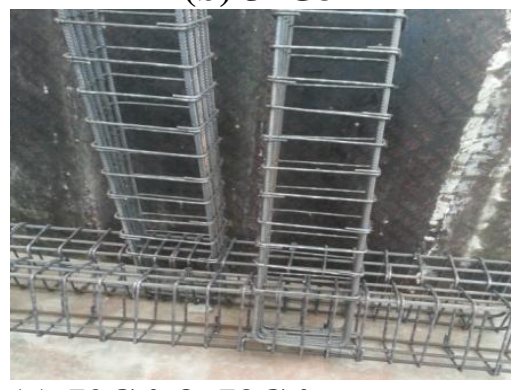

(e) J2G4 \& J3G4

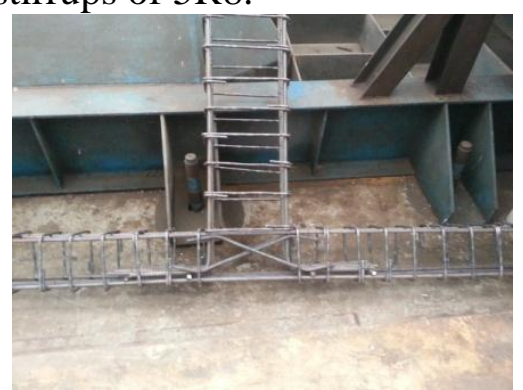

(c) J3G3

Figure 1. Reinforcement arrangement of the tested specimens

Table (1) summarizes the concrete dimensions and reinforcement configuration of the tested specimens, and table (2) shows the mechanical properties of concrete and steel used in the tested specimens. The concrete compressive strength $f_{c}$ in table (2) represents the mean strength value of three standard $(150 \mathrm{~mm} \times 300 \mathrm{~mm})$ cylinders for each specimen. The concrete cylinders were tested on the same day of specimen test.

Table (1), Concrete dimensions and reinforcement configuration of the tested specimens

\begin{tabular}{|c|c|c|c|c|c|c|c|}
\hline \multirow{2}{*}{ Specimen } & \multicolumn{2}{|c|}{$\begin{array}{c}\text { Specimens } \\
\text { dimensions (mm) }\end{array}$} & \multicolumn{2}{|c|}{$\begin{array}{c}\text { Beam } \\
\text { reinforcement }\end{array}$} & \multicolumn{2}{|c|}{$\begin{array}{c}\text { Column } \\
\text { reinforcement }\end{array}$} & \multirow{2}{*}{ Joint details } \\
\hline & $\begin{array}{c}\text { Beam } \\
b \times t\end{array}$ & $\begin{array}{c}\text { Column } \\
\text { b x t }\end{array}$ & Top & Bottom & Top & Bottom & \\
\hline J1G3 & \multirow{4}{*}{$200 \times 300$} & \multirow{4}{*}{$200 \times 200$} & \multirow{4}{*}{$7 \mathrm{~T} 12$} & \multirow{4}{*}{$7 \mathrm{~T} 12$} & \multirow{4}{*}{$5 \mathrm{~T} 12$} & \multirow{4}{*}{$5 \mathrm{~T} 12$} & No shear reinforcement \\
\hline J2G3 & & & & & & & U-shape stirrups 2T12 \\
\hline $\mathrm{J} 3 \mathrm{G} 3$ & & & & & & & Cross bars 2T12 through column only \\
\hline J4G3 & & & & & & & Cross bars $2 \mathrm{~T} 12$ connecting beam and \\
\hline
\end{tabular}


EFFECT OF JOINT DETAILS ON THE BEHAVIOR OF RC BEAM COLUMN CONNECTIONS SUBJECTED TO REVERSED CYCLIC LOADING

\begin{tabular}{|c|c|c|c|c|c|}
\hline & & \multirow{5}{*}{} & & & column \\
\hline J2G4 & & & & Stirrups 3R8 \\
\cline { 1 - 3 } & & & & & Stirrups 5R8 \\
\hline
\end{tabular}

Table (2), Mechanical properties of concrete and steel used in the tested specimens

\begin{tabular}{|c|c|c|c|c|c|c|c|}
\hline \multirow{3}{*}{ Specimen } & \multirow{3}{*}{$\begin{array}{c}\mathrm{f}_{\mathrm{c}}^{\prime} \\
\mathrm{MPa}\end{array}$} & \multicolumn{6}{|c|}{ Steel properties } \\
\hline & & \multicolumn{3}{|c|}{ R8 mm (Plain) } & \multicolumn{3}{|c|}{ T12 mm (Deformed) } \\
\hline & & $\begin{array}{c}\mathrm{f}_{\mathrm{y}} \\
\mathrm{Mpa}\end{array}$ & $\begin{array}{c}\mathrm{f}_{\mathrm{u}} \\
\mathrm{Mpa}\end{array}$ & $\begin{array}{c}\mathrm{E} \\
\mathrm{GPa}\end{array}$ & $\begin{array}{c}\mathrm{f}_{\mathrm{y}} \\
\mathrm{Mpa}\end{array}$ & $\begin{array}{c}\mathrm{f}_{\mathrm{u}} \\
\mathrm{Mpa}\end{array}$ & $\begin{array}{c}\mathrm{E} \\
\mathrm{GPa}\end{array}$ \\
\hline J1G3 & 20.37 & \multirow{6}{*}{245} & \multirow{6}{*}{340} & \multirow{6}{*}{198} & \multirow{6}{*}{460} & \multirow{6}{*}{580} & \multirow{6}{*}{200} \\
\hline $\mathrm{J} 2 \mathrm{G} 3$ & 20.4 & & & & & & \\
\hline J3G3 & 23.7 & & & & & & \\
\hline J4G3 & 20.37 & & & & & & \\
\hline J2G4 & 23.28 & & & & & & \\
\hline J3G4 & 23.28 & & & & & & \\
\hline
\end{tabular}

\subsection{Test setup}

Figure (2) shows the test setup. All specimens were subjected to displacement controlled unidirectional reversed cyclic loading up to failure. The cyclic load was applied to the beam end using a hydraulic actuator after an axial constant load was applied to the column top face by a hydraulic jack. The axial load value was $10 \%$ of the column ultimate capacity. In addition, column and beam loads were measured using electronic load cells. Moreover, five electrical strain gauges were used to measure the steel strain of top and bottom beam reinforcement, columns longitudinal reinforcement, and beam transverse reinforcement as shown in figure (3). Load cells, LVDTs, and strain gauges were wired to a data acquisition system connected to a $\mathrm{PC}$ in order to store measurements and control the loading procedure as shown in figure (4).

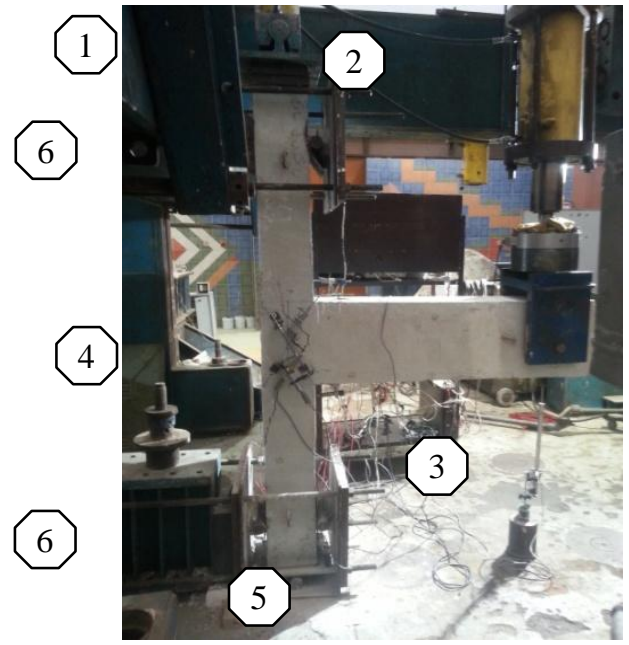

1- $\quad$ Hydraulic jack attached to compression load cell.

2- Hydraulic actuator attached to tension-compression load cell.

3- $\quad$ LVDT to measure beam end displacement.

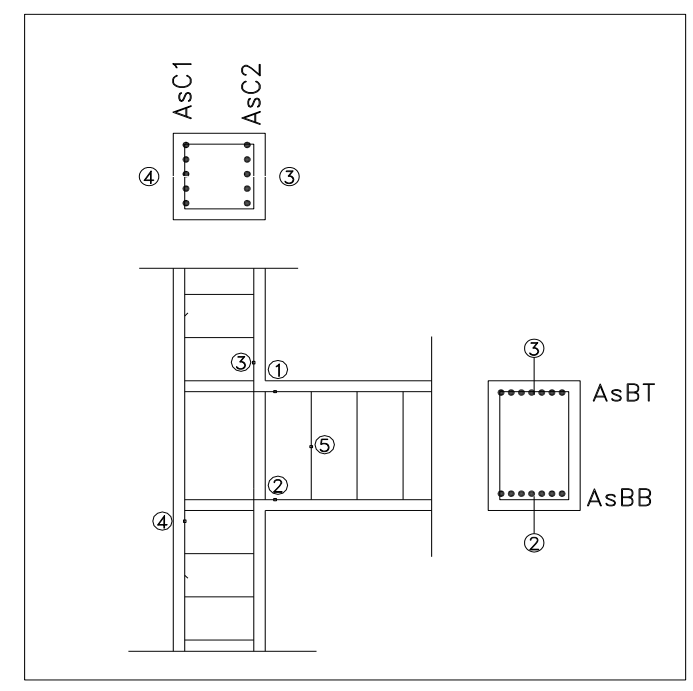

4- $\quad$ LVDTs to measure joint shear distortion.

5- $\quad$ Rigid floor.

6- Reaction frame. 
Figure 2. Test setup

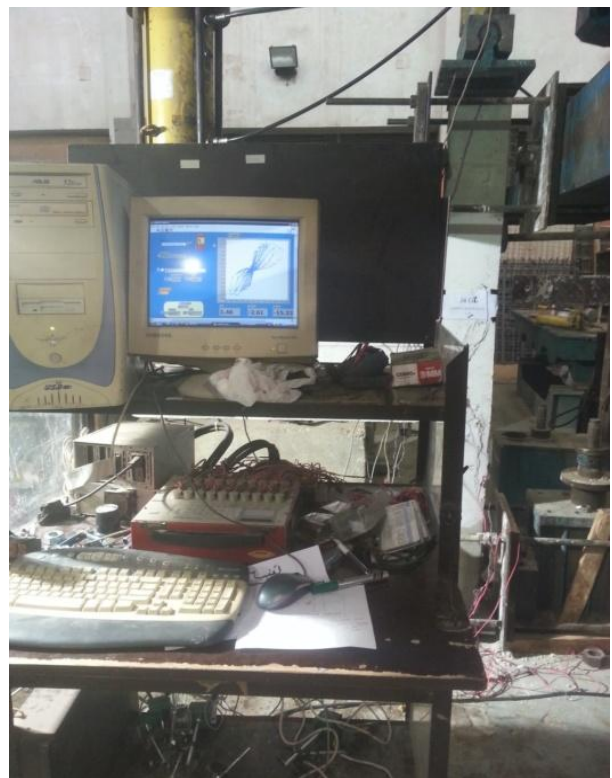

Figure 4. Data acquisition system and PC used for the test.
Figure 3. Location of steel strain gauges.

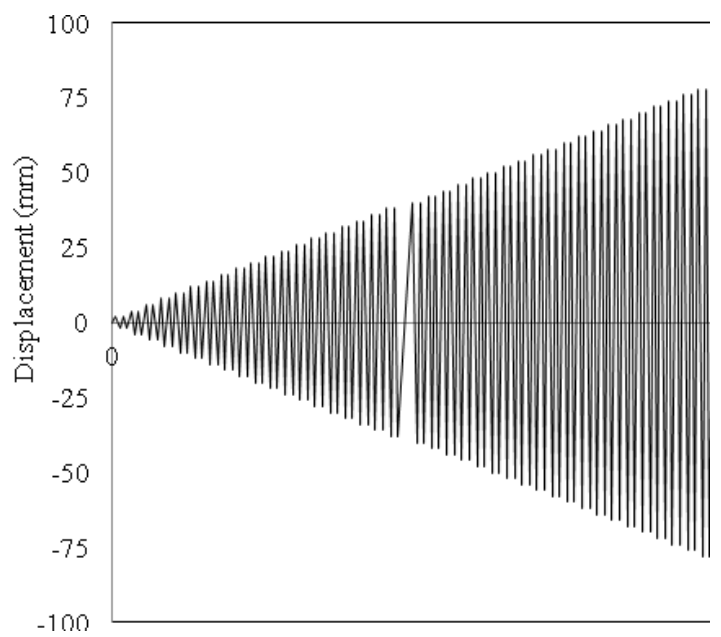

Figure 5. Loading protocol

\subsection{Loading procedure}

The experiments were carried out by applying displacement controlled reversed cyclic load at the beams end while applying constant axial load on the columns. Figure (5) shows the loading protocol applied during the testing procedure. The loading sequence consisted of sets of two equal displacement cycles at specified displacement amplitude of $2 \mathrm{~mm}$. The displacement amplitude was gradually increased every two cycles. Since the actuator stroke was limited to $150 \mathrm{~mm}$ (total), the largest beam end displacement was restricted to $+/-85 \mathrm{~mm}$.

4.0 Experimental results

4.1 Hysteretic load deflection relationships

Figure (6) shows the load verses hysteretic displacement relationships for the tested specimens. The load is considered positive when the beam is pulled up and negative when pushed down. In addition, table (3) presents the values of the experimental response for loading in both directions in terms of maximum force $\left(\mathrm{P}_{\max }\right)$, deflection at maximum force $\left(\Delta_{\max }\right)$, ultimate force $\left(\mathrm{P}_{\mathrm{u}}\right)$, and deflection at ultimate force $\left(\Delta_{\mathrm{u}}\right)$. The ultimate point corresponds to a $20 \%$ strength reduction relative to the maximum strength as implemented by Park and Ang [4].

No significant increase in the ultimate load has been observed for specimens J2G3, J3G3, and J4G3 compared to that of the control specimen (J1G3). For instance, the increase in the ultimate load for specimen J2G3 was $13.08 \%$ and $7.22 \%$ in the upward and downward directions, respectively. In addition, the increase in the ultimate load for specimens J3G3\&J4G3 varied from $2.37 \%$ to $6.23 \%$ for both upward and downward directions. The reinforcement details implemented in specimens J2G3, J3G3, and J4G3 did not contribute to a significant increase in the ultimate load capacity.

On the other hand, a remarkable increase in ultimate loads has been observed for specimens J2G4 and J3G4 compared to that of control specimen (J1G3). The better joint confinement provided by the closed stirrups in specimens J2G4 and J3G4 led to a significant enhancement of the ultimate load capacity. The percentage of increase in the ultimate load varied from $120.64 \%$ to $143.05 \%$ for both upward and downward directions compared to that of the control specimen. However, 
EFFECT OF JOINT DETAILS ON THE BEHAVIOR OF RC BEAM COLUMN CONNECTIONS SUBJECTED TO REVERSED CYCLIC LOADING

figure (7) shows the percentage of increase in ultimate load capacity for all specimens compared to that of control specimen.

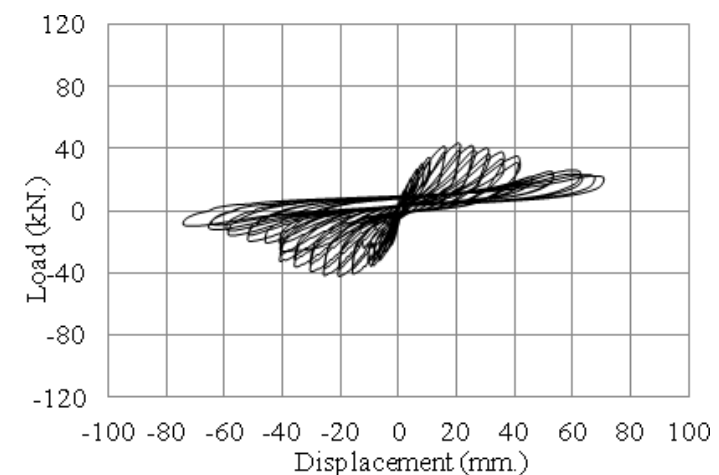

(a) J1G3

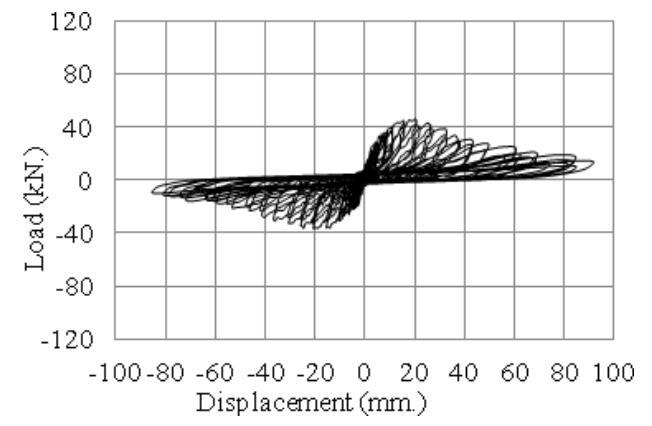

(c) J3G3

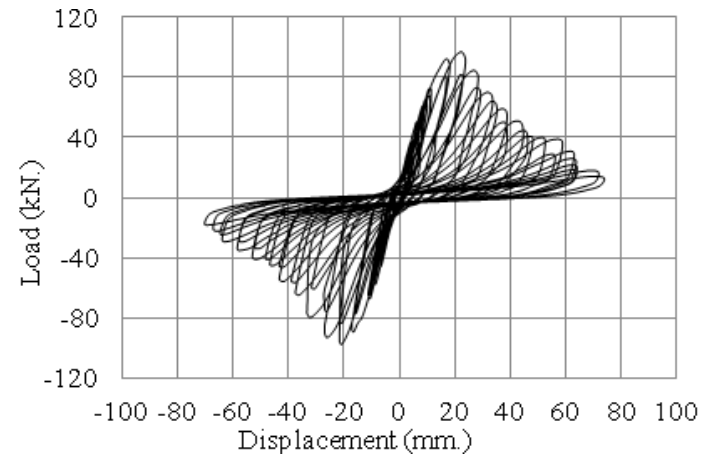

(e) J2G4

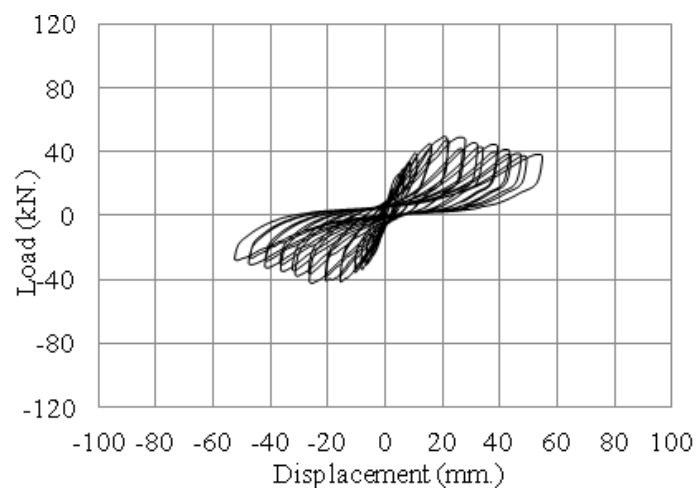

(b) J2G3

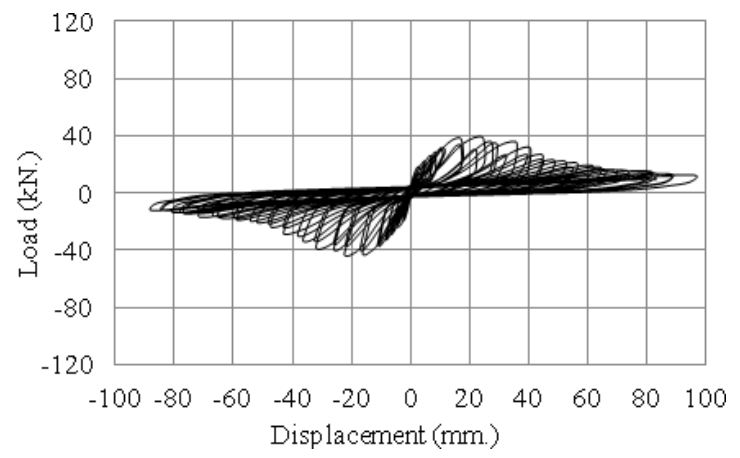

(d) J4G3

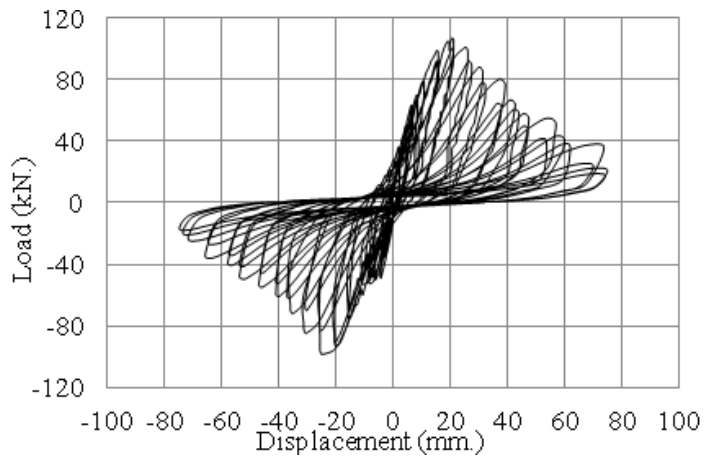

(f) J3G4

Figure 6. Hysteretic load displacement relationship for the tested specimens

Table (3), Ultimate loads and maximum displacements of the tested specimens.

\begin{tabular}{|c|c|c|c|c|c|c|c|c|}
\hline \multirow{2}{*}{ Specimens } & \multicolumn{2}{|c|}{$\begin{array}{c}\text { Maximum load } \\
\left(\mathrm{P}_{\mathrm{u}}\right) \mathrm{kN} .\end{array}$} & \multicolumn{2}{c|}{$\begin{array}{c}\text { Displacement corresponding } \\
\text { to } \\
\end{array}$} & \begin{tabular}{c|c|c|c|c|c|c|} 
maximum load $\left(\Delta_{\max }\right) \mathrm{mm}$. \\
\cline { 2 - 9 }
\end{tabular} & \multicolumn{2}{c|}{$\begin{array}{c}\text { Ultimate load } \\
\left(\mathrm{P}_{\mathrm{u}}\right) \mathrm{kN} .\end{array}$} & \multicolumn{2}{c|}{$\begin{array}{c}\text { Displacement } \\
\text { corresponding to } \\
\text { ultimate load }\left(\Delta_{\mathrm{u}}\right) \mathrm{mm} .\end{array}$} \\
\hline J1G3 & 42.29 & 43.96 & 20.00 & 20.62 & 33.80 & 35.17 & 38.50 & 40.70 \\
\hline J2G3 & 45.30 & 49.72 & 20.39 & 20.44 & 36.24 & 39.77 & 28.32 & 43.70 \\
\hline J3G3 & 43.25 & 45.90 & 24.58 & 20.08 & 34.60 & 36.72 & 32.80 & 33.38 \\
\hline J4G3 & 43.70 & 46.70 & 20.00 & 22.77 & 34.96 & 37.36 & 33.65 & 33.80 \\
\hline
\end{tabular}


EFFECT OF JOINT DETAILS ON THE BEHAVIOR OF RC BEAM COLUMN CONNECTIONS SUBJECTED TO REVERSED CYCLIC LOADING

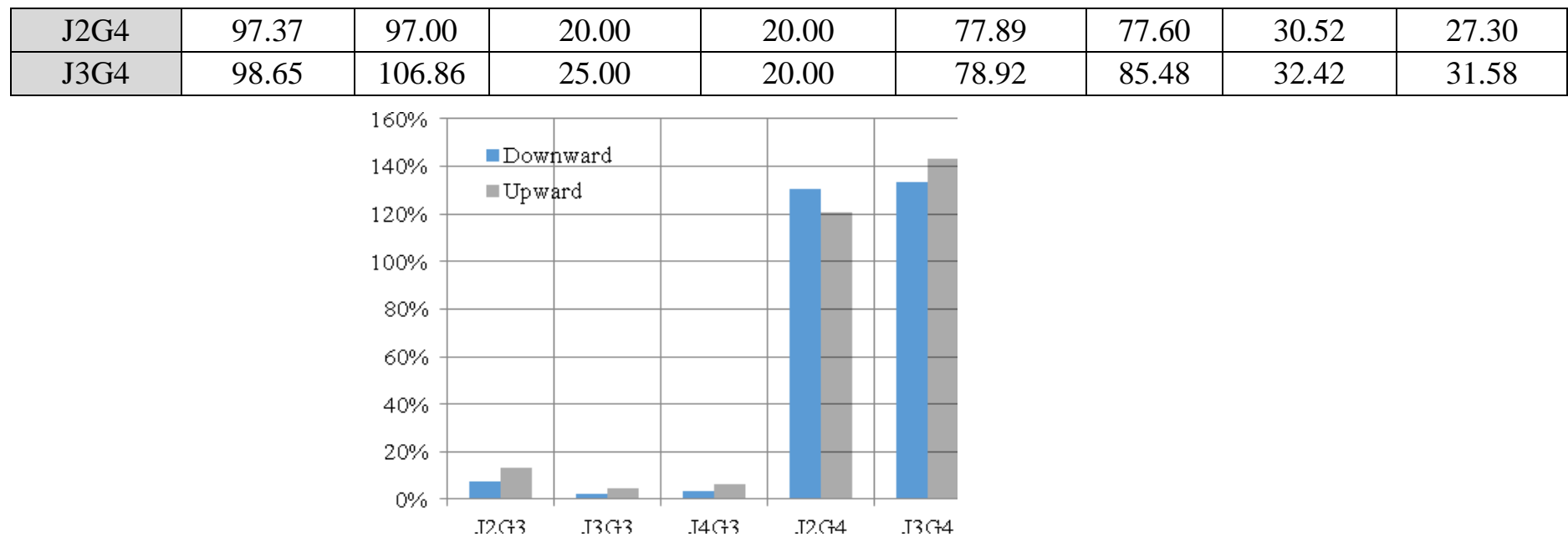

Figure 7. persentage of increase of ultimate load capacity compared to control specimen.

\subsection{Evolution of energy dissipation}

The hysteretic energy dissipated evolution, defined as the area under the hysteretic forcedisplacement diagrams [3], is shown in figure (8). A comparison of the energy dissipated for all the tested specimens was conducted. This comparison was carried out at beam displacement of 40 $\mathrm{mm}$. All specimens dissipated more energy than the control specimen. Namely specimen J2G3 dissipated $+143.70 \%$, specimen J3G3 dissipated $+96.01 \%, \quad$ specimen J4G3 dissipated $+109.13 \%$, specimen J2G4 dissipated $+369.53 \%$, and specimen J3G4 dissipated $+419.60 \%$. Despite specimens with joint U-shaped stirrups and joint cross bars (J2G3, J3G3, and J4G3) displayed higher energy dissipation than the control specimen; specimens with closed stirrups in the joint region dissipated higher energy than specimens with other joint details.

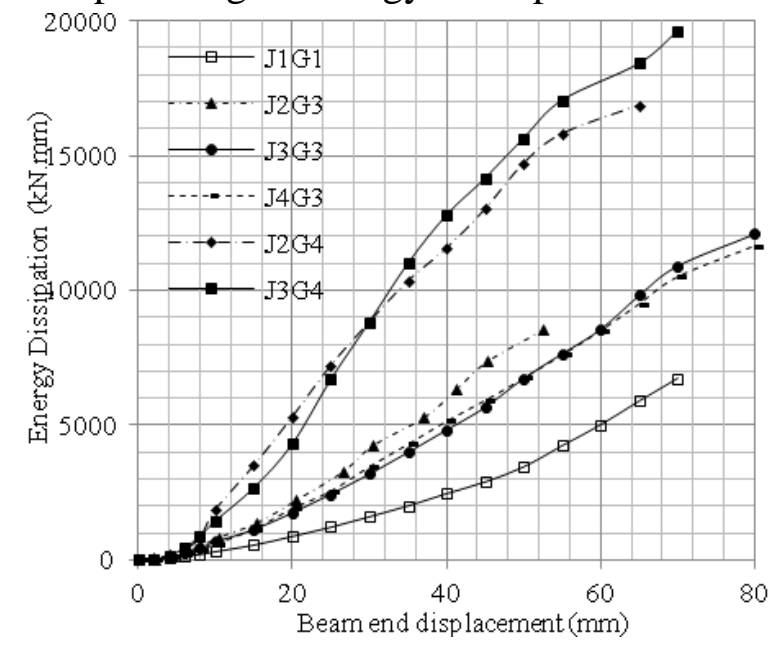

Figure 8. Energy dissipation evolution for the tested specimens.

\subsection{Joint shear strength}

Figure 9 shows the normalized joint shear strength versus corresponding beam vertical displacement of the tested specimens. Shear strength is represented in a normalized state by dividing the shear strength by the square root of the concrete compressive strength as follows: 


$$
\left[v_{j}\right]_{\overline{1}}=\left[\frac{v_{j u}}{\sqrt{f_{c}^{2}}}\right]
$$

The ultimate joint shear strength for the tested specimens was calculated at a corresponding beam load equal to $80 \%$ of the maximum load. The horizontal joint shear stress in the joint core $\left(v_{j h}\right)$ was calculated using the following equation [3]:

$v_{j \boldsymbol{h}}=\frac{V_{j h}}{b_{j} \boldsymbol{h}_{c}}$

Where $V_{\mathrm{jh}}$ is the horizontal shear force acting on the joint and $b_{\mathrm{j}}$ is the width of joint core. The joint shear force was calculated using the following equation [3].

$V_{j h}=\frac{M_{b}}{j d}-V_{\text {coI }}$

Where $\mathrm{M}_{\mathrm{b}}$ is the beam moment, and jd is the distance between the beam tensile reinforcement and the mid of the concrete compressive block, it was taken as $90 \%$ of the total beam height. Table (4) shows the values of the ultimate load and ultimate shear strength of the tested specimens.

Specimen J3G3 (with crossbars lapping each side of the column longitudinal bars together) showed a deteriorated shear strength compared to that of control specimen. In addition to the absence of joint sufficient confinement, column axial forces passing through the joint cross bars contributed to the increase of transverse tensile stress and led to joint premature shear failure.

In addition, specimen J4G3 (with crossbars lapping between beam top and bottom reinforcement) showed increased ultimate shear strength of about $8 \%$ compared to that of control specimen. Moreover, specimens provided with joint closed stirrups (J2G4\&J3G4) showed enhanced joint shear strength compared to that of the control specimen. The percentage of joint shear strength increase was $108 \%$ and $128 \%$ for specimens J2G4 and J3G4 respectively. Joint stirrups provided better confinement for joint concrete compressive struts and contributed to carrying joint shear forces.

Furthermore, the U-shaped joint stirrups enhanced the ultimate shear strength of specimen J2G3 with only $18 \%$ compared to that of control specimen. This enhancement in joint shear strength is relatively low considering the high amount of stirrups ratio provided for the latter specimen. Therefore, the shape of stirrups turned out to play a great role in increasing the ultimate joint shear strength. Unlike closed stirrups, U-shaped stirrups did not enhance the joint confinement significantly. 


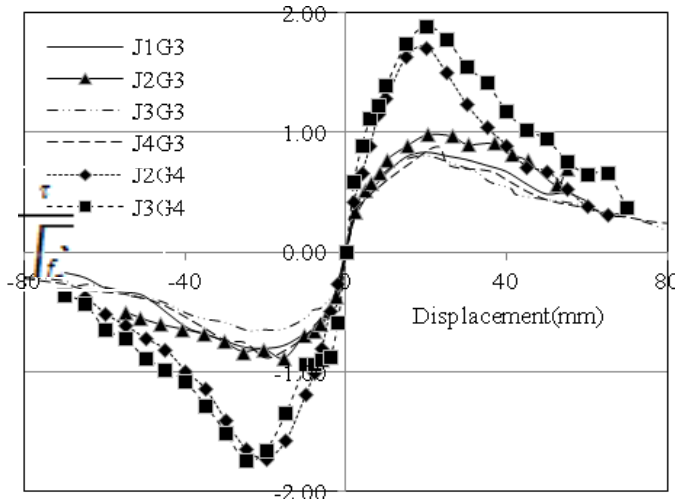

Figure 9. Normalized shear strength verses corresponding beam displacement of the tested specimens.

Table (4), Ultimate load and ultimate Joint shear strength of the tested specimens.

\begin{tabular}{|c|c|c|c|c|c|}
\hline 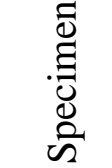 & $\begin{array}{c}\mathrm{P}_{\mathrm{u}} \\
(\mathrm{kN})\end{array}$ & $\begin{array}{c}\mathrm{f}_{\mathrm{c}} \\
(\mathrm{Mpa})\end{array}$ & $\begin{array}{c}\mathrm{V}_{\mathrm{jh}} \\
(\mathrm{kN})\end{array}$ & $\begin{array}{c}v_{j u} \\
(\mathrm{Mpa})\end{array}$ & {$\left[y_{j}\right]_{E x p}=\left[\frac{v_{j u}}{\sqrt{f_{c}^{*}}}\right]_{E x p}$} \\
\hline $\mathrm{J} 1 \mathrm{G} 3$ & 35.16 & 20.37 & 134.09 & 3.35 & 0.74 \\
\hline J2G3 & 39.77 & 20.40 & 158.65 & 3.97 & 0.88 \\
\hline J3G3 & 36.72 & 23.70 & 140.01 & 3.50 & 0.72 \\
\hline J4G3 & 37.36 & 20.37 & 142.45 & 3.56 & 0.79 \\
\hline J2G4 & 77.90 & 23.28 & 297.01 & 7.43 & 1.54 \\
\hline J3G4 & 85.49 & 23.28 & 325.95 & 8.15 & 1.69 \\
\hline
\end{tabular}

\subsection{Comparison of experimental shear strength with some models.}

Values of the joint shear strength of the tested specimens were compared with Vollum [6], Bakir [5], Hegger [2], and Tran et.al (2009) [7] models, as well as ACI-352 provisions [1]. Figure (10) and table (5) show the performance of the selected models against experimental results. Specimens J3G3 and J4G3 were excluded from comparison because they included non-traditional joint reinforcement.

The comparison indicated that ACI-352 provisions overestimated the shear strength of specimens J1G3, and J2G3. On the contrary, ACI-352 predictions were conservative for specimens with closed stirrups. This was expected since the contribution of shear reinforcement is neglected in the ACI-352 formula.

Vollum model predicted the shear strength of the unreinforced joint accurately, the value of $\left[\gamma_{\tilde{j}}\right]$

was 1.01. However, Vollum model overestimated the shear strength of specimen with U-shaped stirrups (J2G3) and underestimated the shear strength of specimens with closed stirrups (J2G4, and J3G4). 
In addition, Tran model predicted the shear strength of joints with stirrups accurately, the value $\left[\gamma_{j}\right]$

of

was 0.96 and 1.04 for specimens J2G4 and J3G4, respectively. Conversely, Tran model overestimated the shear strength of the other specimens.

All models overestimated the shear strength of specimen with U-shaped stirrups (J2G3). However, Vollum model and ACI-352 predictions were the closest to experimental results with a $\left[\gamma_{\tilde{j}}\right]$

value of of 0.83 and 0.88 for Vollum model and ACI-352 provision, respectively.

Moreover, Bakir and Hegger models overestimated the shear strength of specimens J1G3 (joint with no shear reinforcement) and J2G3 (joint with U-shaped stirrups). On the other hand, Baker and Hegger predications were conservative for specimens with closed stirrups (J2G4, J3G4).

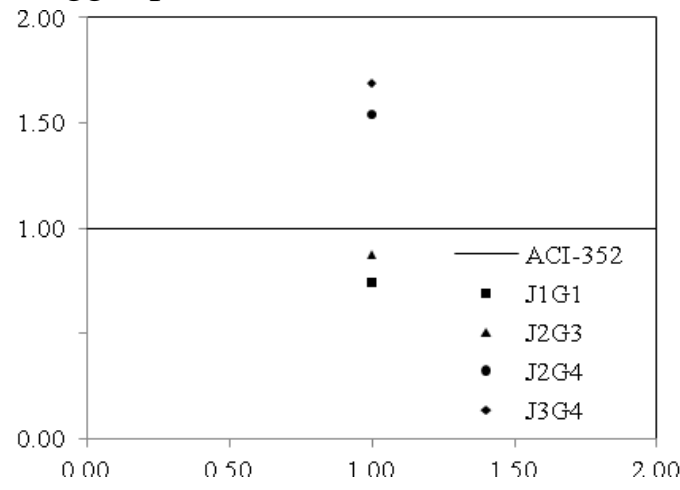

(a)

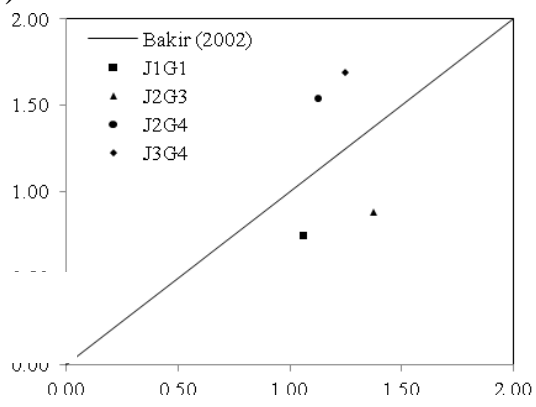

(c)

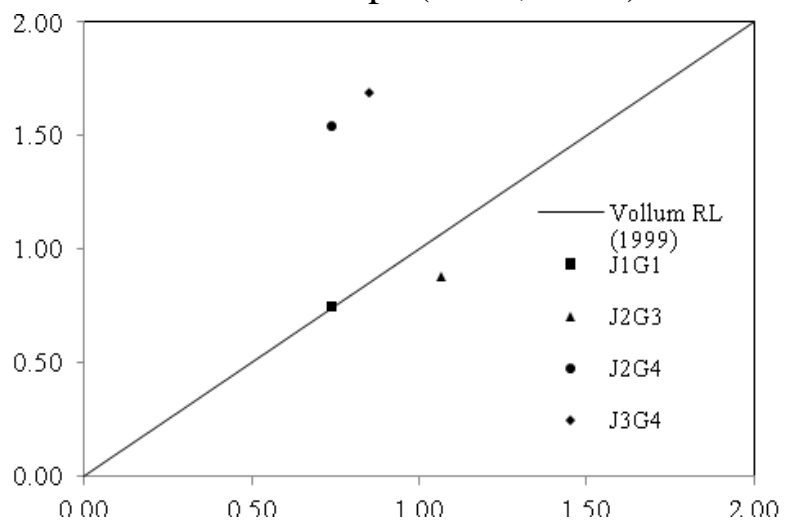

(b)

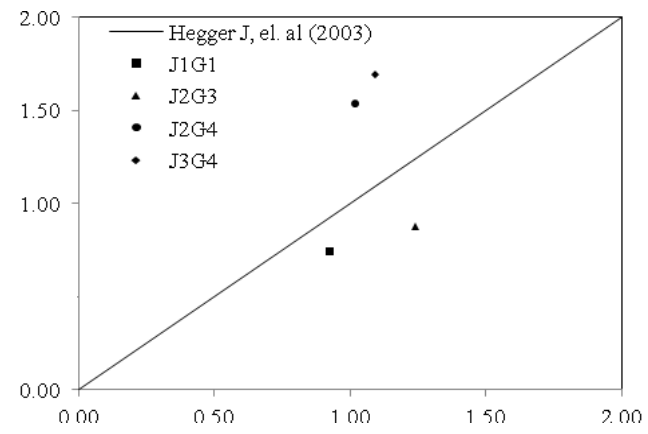

(d) 


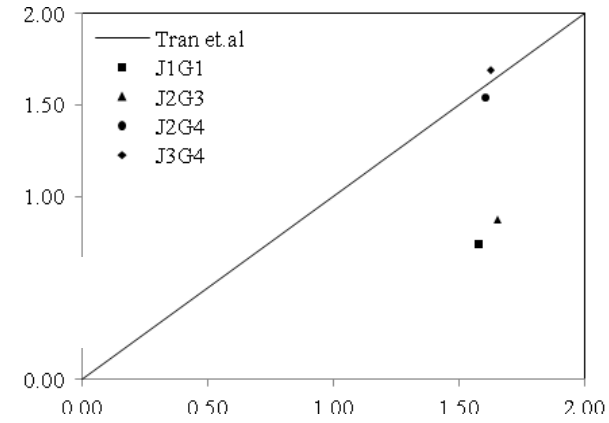

Figure (10). Performance of different models against experimental results: (a) ACI-352 (b) Vollum (1999), (c) Bakir (2002), (d) Hegger et.al (2003), (e) Tran et.al (2009)

(e)

Table 5. Experimental joint ultimate shear strength compared to models predictions.

\begin{tabular}{|c|c|c|c|c|c|c|c|c|c|c|c|}
\hline \multirow{2}{*}{ 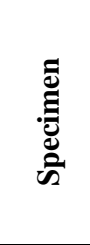 } & \multirow{2}{*}[\gamma_{j}]{$_{E x p}=\left[\frac{v_{j u}}{\sqrt{f_{c}}}\right.$} & \multicolumn{3}{|c|}{$\left[y_{j}\right]_{\text {Model }}=\left[\frac{v_{j u}}{\sqrt{f_{c}}}\right.$} & \multicolumn{2}{|l|}{ Model. } & \multicolumn{5}{|c|}{$\left[\gamma_{j}\right]$} \\
\hline & & $\begin{array}{c}\text { Vollum } \\
\& \\
\text { Newman }\end{array}$ & Bakir & $\begin{array}{l}\text { Hegge } \\
r \text { et. al. }\end{array}$ & $\begin{array}{l}\text { Tran } \\
\text { et.al }\end{array}$ & ACI-352 & $\begin{array}{c}\text { Vollum } \\
\& \\
\text { Newman }\end{array}$ & Bakir & $\begin{array}{c}\text { Hegger } \\
\text { et. al. }\end{array}$ & $\begin{array}{l}\text { Tran } \\
\text { et.al }\end{array}$ & ACI-352 \\
\hline J1G3 & 0.74 & 0.74 & 1.06 & 0.92 & 1.58 & 0.996 & 1.01 & 0.70 & 0.80 & 0.47 & 0.75 \\
\hline J2G3 & 0.88 & 1.06 & 1.37 & 1.24 & 1.66 & 0.996 & 0.83 & 0.64 & 0.71 & 0.53 & 0.88 \\
\hline J2G4 & 1.54 & 0.74 & 1.13 & 1.02 & 1.61 & 0.996 & 2.08 & 1.36 & 1.51 & 0.96 & 1.55 \\
\hline J3G4 & 1.69 & 0.85 & 1.25 & 1.09 & 1.63 & 0.996 & 1.99 & 1.36 & 1.55 & 1.04 & 1.70 \\
\hline
\end{tabular}

\subsection{CONCLUSIONS}

1. The use U-shaped stirrups enhanced the cyclic behavior of the exterior beamcolumn connections compared to that of joint without shear reinforcement. For instance, the ultimate load increase was about $13.08 \%$ and $7.22 \%$ in the upward and downward directions, respectively. In addition, energy dissipation increased by about $143.70 \%$ and joint shear strength increased by about $18.90 \%$.

2. Adding crossbars in joint region lapping between column reinforcement affected the joint shear strength negatively, despite the increase in energy absorption capacity.

3. Adding crossbars in the joint region lapping beam reinforcement with column reinforcement led to slight enhancement in the cyclic behavior of beam-column assembly. For example, energy dissipation increase was about $109.13 \%$, and ultimate joint shear strength increase was about $6.70 \%$.

4. Specimens with closed stirrups induced superior behavior over other specimens with different joint details. The increase of stirrups ratio led to an increase in the ultimate joint strength and energy absorption capacity.

5. Vollum model accurately predicted the ultimate joint shear strength of specimen without shear reinforcement. However, for specimens with joint closed stirrups, Tran model predictions were the most accurate among other models.

6. ACI-352, Bakir model, and Hegger model overestimated the joint shear strength of specimen without joint transverse reinforcement. On the other hand, their predictions of the joint shear strength of specimens with closed stirrups were conservative.

7. All empirical models investigated in this study failed to predict the ultimate joint shear strength of specimens with U-shaped stirrups. There is a need to include a parameter to account for the stirrup shape.

\section{REFERENCES}

[1] ACI (American Concrete Institute) (2002) ACI 352-R02, "Recommendations for design 
of beam-column joints in monolithic reinforced concrete structures", ACI, Farmington Hills, MI, USA.

[2] Josef Hegger, Alaa Sherif, Wolfgang Roeser, "Nonseismic design of beam-column joints", ACI structural journal, 2003; 100 (5), 654-664.

[3] José Melo, Humberto Varum, Tiziana Rossetto, "Cyclic behaviour of interior beamcolumn joints reinforced with plain bars”, Earthquake Engineering \& Structural Dynamics, 2015; 44, 1351-1371

[4] Park YJ., Ang AHS, Wen YK., "Damage limiting aseismic design of buildings", Earthquake Spectra, 1978; 3 (1), 1-26.

[5] P.G. Bakir, H.M. Boduroğlu, "A new design equation for predicting the joint shear strength of monotonically loaded exterior beam-column joints", Engineering structures, 2002; 24, 1105-1117.

[6] R.L. Vollum, J.B. Newman, "Strut and tie models for analysis / design of external beamcolumn joints", Magazine of concrete research, 1999; 51 (6), 415-425.

[7] Tung M. Tran, Thong M. Pham, Muhammad N. S. Hadi, "A new empirical model for shear strength of reinforced concrete beam-column connections", Magazine of concrete research, 2014; 66 (10), 514-530. 